\title{
Application of Lean Agile Resilient Green Paradigm Framework on China Pakistan Economic Corridor: A Case Study
}

\author{
KHAN RAI WAQAS AZFAR*, NAEEM SHAHZAD*, AND SADAF MUMTAZ** \\ RECEIVED ON 14.07.2016 ACCEPTED ON 21.02.2017
}

\begin{abstract}
China has recently emerged as the technological and economic giant and an attractive place for investment for MCNs (Multi-National Companies). Many of the high ranked MNC's have shifted their production facilities to China due to low production cost.Finished products are transported through sea routes passing through Singapore and Sri Lanka, to different Middle Eastern, European and American countries. This major transition has lead to complete transformation of the global SC (Supply Chain); which resulted into extended transportation, distances and led time,thus affecting the four paradigms of SC i.e. lean, agile, resilient and green. Effective integration of all of these paradigms poses a significant challenge for the academia and industry related to SC.The common and critical success factors among these paradigms are reduction in transportation distances and most importantly lead time. Scenario planning technique is used in this study to analyze different trade routes originating from central China. CPEC (China Pakistan Economic Corridor) was identified as the most feasible and economical route owing to its reduced transportation distance and led time. CPEC route also provides us an opportunity to perform trade-offs between the four paradigms; focusing primarily on the critical success factors. These tradeoffs provide us a common ground which lead us to propose a new LARG (Lean Agile Resilient Green) framework. This framework was further validated with the help of results obtained from CPEC case study using scenario planning technique.
\end{abstract}

Key Words: Supply Chain Management, Lean Agile Resilient Green, Paradigm, Framework, Scenario Planning, Case Study.

\section{INTRODUCTION}

$\longrightarrow$

lobalization has put overwhelming pressure on transportation and logistics, which hascompelled this sector to improve its practices [1]. Early awareness of latest innovations, knowledge about cutting edge technologies, finding best location of retail, cheapest price of merchandises, minimum delivery and lead time are few important factors which a logistics manager has acquired over the years in the global competitive environment [2]. Every consumer desires that cutting-edge innovative product would reach to him at earliest, but at a competitive price. Globalization has compelled logistics and transportation business to enhance their standards, so that these businesses could be proficient [3].

* $\quad$ Military College of Engineering, National University of Sciences \& Technology, Risalpur.

** $\quad$ Fauji Foundation College for Girls, New Lalazar, Rawalpindi.

Mehran University Research Journal of Engineering \& Technology, Volume 36, No. 3, July, 2017 [p-ISSN: 0254-7821, e-ISSN: 2413-7219] 
Supply Chainis described as network that links various activities, from the end customer to the end suppliers, passes through services and manufacturing, so as the flow of money, material and information could effectively be managed to ultimately meet the requirements of the businesses [4]. In business nowadays it is assumed that SC's should compete in the market instead of organizations [5].

SCM (Supply Chain Management) considered an important factor for better achievement if the organizational goal, e.g. improved customer service, enhanced competitiveness and increased profitability [6]. Reichhart [7] definedlean paradigm as minimizing the waste in SC, while ensuring that right product should be available to end customer at right location and time. Baramichai [8] definedagileparadigm as the integration of the business allies to enable new capabilities in order to answer the rapidly changing, persistently fragmenting markets. Nowadays market is categorized by highest level of volatility and turbulence, resilience paradigm is described as the SC's ability to cope-up with the unexpected turbulences [9]. Srivastava [10] defined Green paradigm as "integrating environmental thinking into SCM, including product design, material sourcing and selection, manufacturing processes, delivery of the final product to the consumers as well as end-of-life management of the product after its useful life".

The fourSC paradigms i.e., lean, agile, resilient and green have extensively been researched independently, but recently, researchers have emphasized on integration of these four paradigms into one LARG paradigm [11-17]. " However, the simultaneous integration of lean, agile, resilient, and green paradigms in SCM may help SC's to become more efficient, streamlined and sustainable" [11].

The recent research carried out in LARG paradigm is restricted tothe formulation of conceptual framework. No serious effort has been carried to empirically validate these conceptual models. LARG is very powerful paradigm in SCM subject area. If a new conceptual framework for LARG paradigm could be theorized as well as validated through case study; which could facilitate the LARG paradigm practical implementation. Moreover this validated LARG paradigm would really be excellent value addition in existing body of knowledge. Therefore the main objective of this research paper is to validate the conceptually presented LARG paradigm, through Chinese's logistics case study. In first step through deductive research approach, a conceptual framework was theorized from the literature review. Subsequently this framework was validated through application of scenario development and analysis technique in a Chinese's logistics case study. This paper is structured as follows. Following to the introduction, a literature review from a SCM viewpoint is presented. After this, proposed conceptual framework is discussed, as how common ground for LARG paradigm can be achieved. Subsequently four scenarios are developed and analyzed for a Chinese's logistics case study. Finally, before some conclusions are drawn, the proposed conceptual framework is validated by using scenario planning in Chinese's logistics case study.

\section{LITERATURE REVIEW}

Reduction in setup time seems to be critical in the linkage among product quality, lean production, and overall performance of business [18]. To counter the ambiguity in the decision constraints, flexibility is the obligatory requirement in the supply chains. SCs can only adapt the requisite changes if it is highly agile and flexible in nature [19].

Nowadays real competition is between SC rather than businesses. Present SCM philosophies e.g. LARG are previously analyzed individually as management paradigms $[14,20]$. Although the adoption of lean philosophies may promote increased profitability; however the lean practices may leave a high level of reliance on human resources [21]. Sustainability has become very important to business

Mehran University Research Journal of Engineering \& Technology, Volume 36, No. 3, July, 2017 [p-ISSN: 0254-7821, e-ISSN: 2413-7219] 
researchers and practitioners over the last few decades. These concerns has got due attention after rapid exhaustion of natural resources and also due to awareness about corporate social responsibility [22].

The transportation operation, like other supply chain operations should essentially add value. This can be achieved through proper order accomplishments and reduction in lead times. The multifaceted supplier's network and the delivery channels essentially are efficient and the visibility within the supply chain is a major cause of competitive advantage [23]. Espadinha [16] found that due to bigger competition and huge market pressures it is not inexpensive to implement newest SCM paradigms e.g. LARG due to the problem faced during interoperability of these paradigms.

Azevedo [11] proposed a conceptual model in which LARG practices and SCM attributes are proposed. They used causal loop diagrams to symbolize the relationships among different paradigm's practices and attributes of SC. But the relationships were established from the literature review only. Which could only imitates a limited view of complex SCM dynamics. The tradeoffs among LARG paradigms must be appreciated well, to help enterprises and supply chains to be more sustainable, streamlined and efficient. It is quite necessary to improve an understanding of the affiliations among the LARG paradigms [15].
Carvalho [24] gives an overview of key divergences and synergies among the LARG paradigms. There is strong indication that LARG paradigms complement each other. According to Carvalho [24], the execution of these paradigms in the SCM creates synergies; in a manner that certain SC features should be managed, e.g. integration-level, production lead-time, transportation lead-time and frequency of informationwhich is presented in Table 1. However, the influence of each paradigm execution on the characteristics scale may be changed. The lean practices or paradigm contributes to the reduction of transportation lead-time and production lead-time; which promote reduction in total leadtime and ultimately minimizes total waste. Although the resilient paradigm, also recommends that lead-time should be reduced [25,26].

LARG are independently quite fascinating paradigms; but above literature review found that a big gap prevails to formulate and implement a tradeoff strategy among LARG paradigms of SCM. This trade off strategy should found a common ground where we can align LARG paradigms for synergetic results. This research gap is required to be fulfilled urgently; so that we can perform better tradeoffs among LARG paradigms where we can get maximum synergetic benefits and minimum divergences; to fulfill this research gap following LARG paradigm framework is proposed.

TABLE 1. SYNERGIES AND DIVERGENCES REGARDING LARG PARADIGMS [24]

\begin{tabular}{|c|c|c|c|c|c|}
\hline $\begin{array}{c}\text { Supply Chain } \\
\text { Attributes/Paradigms }\end{array}$ & Lean & Agile & Resilient & Gran & \\
\hline Information Frequency & \multirow{2}{*}{ Increase } & \multirow{2}{*}{ Increase } & \multirow{2}{*}{ Increase } & Without Consequence & \multirow{4}{*}{ Synergies } \\
\hline Integration Level & & & & Increase & \\
\hline Production Lead Time & \multirow{4}{*}{ Decrease } & & & & \\
\hline Transportation Lead Time & & & & & \\
\hline Capacity Surplus & & Increase & \multirow{3}{*}{ Increase } & \multirow{3}{*}{ Decrease } & \multirow{3}{*}{ Divergences } \\
\hline Inventory Level & & Decrease & & & \\
\hline Replenishmnt Frequency & Increase & Increase & & & \\
\hline
\end{tabular}

Mehran University Research Journal of Engineering \& Technology, Volume 36, No. 3, July, 2017 [p-ISSN: 0254-7821, e-ISSN: 2413-7219] 


\section{LARG PARADIGM FRAMEWORK}

Merchandises can be manufactured with one of four discrete SC structures; built for order, assemble for order, design for order and make for stock. Every one SC configuration is appropriate for diverse merchandises based on its demand characteristics. The entire SC configuration orientates its manufacturing and logistics procedures in a different way centered on its strategic significances. Practical repercussions could be high volume production, with uncertain and low demand; that products could be matched with lean SCM paradigm, enabled by effective procedures. Whereas low volume production, with high uncertain conditions; merchandises should be coordinated with agile SCM paradigm, enabled through flexible procedures. Medium volume production and demand medially uncertain conditions; products should be coordinated with leagileSCM paradigm, enabled through combination of flexible and effective procedures [27]. Likewise tradeoffs between LARG could be carried out to balance out production, demand and supply conditions. But if the aim is to achieve synergetic results from production, demand and supply conditions: Then we have to evolve a common paradigm strategy through attaining common ground where LARG paradigms could be align; which would be implemented through tradeoffs of flexible and effective procedures. To achieve synergetic results from existing four SCM paradigms, a central common ground has been attainted through tradeoffs among four existing SCM paradigms. New proposed LARG Paradigm in Fig. 1 is based on the same central common ground.

In Fig. 1on one side there is lean paradigm and on the opposite side we have resilient SCM paradigm, where both have contradicting and diverging practices. First lean scenario tends to have zero inventories [27], whereas in second case of resilient scenario ideally demands sufficient stock to recover from disruption caused by any disaster [28]. Likewise on one side is the green SCM paradigm and on exactly opposite side is the agile SCM paradigm, again both have contradicting and diverging practices. In green SCM paradigm scenario has minimum trip with maximum inventories load, whereas agile SCM

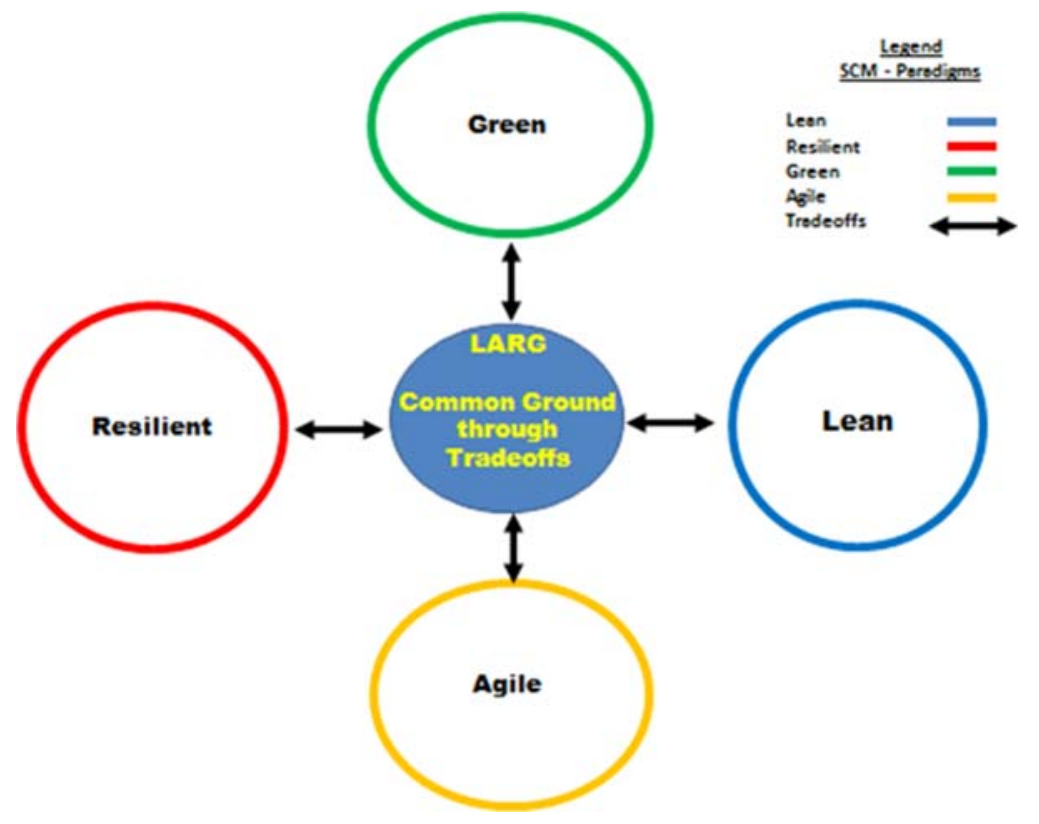

FIG. 1. LARG PARADIGM FRAMEWORK BASED ON COMMON GROUND,ADAPTED FROM [12] 
paradigm scenario practices dictates that there should be maximum number of trip; to meet the demand in quickest possible time [29]. So it is quite evident that all paradigms have diverging and contradicting requirements. If optimum advantage is desired from these SCM paradigms, a common ground should be acquired first, by performing tradeoff among these four SCM paradigms. This common ground will provide a platform from where advantages of all four SCM paradigms could be achieved, instead of pre-selecting any one particular SCM paradigm.

This proposed LARG is a new paradigm which enables organizations to remain at central position till the time all the production, demand and supply conditions are in steady balance state. If balance changes in any one area of production, demand or supply and situation stresses to choose any one particular SCM paradigm then according to situation any one out of four existing SCM paradigms could temporarily be adopted. Once production demand-supply situation normalizes back to steady state, then central common ground should be occupied again, till the time new disruption may not occurred; in this way inertia is also imparted in the system [12].

\section{CENTRAL CHINA LOGISTICS CASE STUDY}

In the last two decades emergence of China as technological and economic gigantic is a disruptive phenomenon i.e. China's changeover from one of the slowly developing economies of the world to themost developedeconomy, because of the factors such as; mass-customized production capability, massive resources and cheap labour[30-32]. Growing international inflation lead most of the manufactured product exporting countries like United States to look for cheap alternatives, above mentioned factors transformed china to become leading exporting country. China has liberalized its central and western region as duty free zone, so that this relatively under developed region can flourish. To grab this opportunity most of industry has shifted to this region, which has transformed central China into industrial cluster [33,34]. But this region is deprived of direct access to coastal harbours, the coastal line of China is approximately more than 1,350 $\mathrm{nm}$ (nautical miles) away from China central region which possess great challenge to achieve critical success factors of logistics and SCM practices. It is the requirement ofthe businesses and SC managers to linkChina central with central European cities straightthrough land route. Moreover, even this route could be extended to North American continent by passing through the Atlantic Ocean. Research had been carried out recently to consider the possibilities of linking central part of the China directly with the Europe;the possibility has been checked even for Arctic Ocean whether this route could be used for ships or otherwise $[35,36]$. It was learnt after research that these are just alternative possibilities but are not cost effective options.

The inventories warehoused in perfectly positioned warehouses could play a significant part in global SCM [37]. To devisea logistic related strategy, South Asian and Middle Eastern regions hasa crucial deficit of pragmatic studies $[38,39]$ which was one of strong basis for conducting this study. This case study concentrates on identification of prospective route possibilities in general, as well as finding best possible shortest route, from Central-China to MiddleEastern countries, African, European and North American continents. A sustainable transportation route is acknowledged for European - South East Asian region, by exploiting geographical locations and convert this exploitation into economic benefits; moreover for managing global SCM efficiently.

\section{METHODOLOGY}

The methodology of this research is application of the scenario planning in logistics case study. Scenario planning is technique which is quite relevant to this case study. There is quite considerable amount of literature in which different approaches of scenario planning have been used. But most important among these approaches 
is based upon the approach developed by shell/SRI [4043]. Literature review reveals that case study method has been used quite frequently in logistics and SCM [44-47]. Holmqvist[40] used scenario development approach in a logistics case study. Herbert Kahn is known for his initial development of scenarios as technique for creating quite accurate forecasts.

This LARG paradigm framework has been tested through this logistics case study, in which different scenarios for route options were generated. In this case study all the logistics trade routes originates from Central China and terminate either at Middle Eastern, Western European or Easter American Countries cities. To measure the total distances or lead time for any one particular logistics route scenario, it was divided into many small segments, the distance and lead time for each segment is calculated separately. Reason of segmentation is that land and sea have different modes of transportation; different transportation time and most importantly different fuel consumption. That's why distances for each segment from industrial cities to end port cities are calculated separately; so that ultimately these transportation distances could be resulted into accurate lead times. The distances between two geographical positions are calculated in different ways:

(1) To measure shortest distance between two localities: Aerial distance is measured between two locations (shortest possible straight bird's path) by using Zipoid a GIS software. The distance was calculated in $\mathrm{nm}$. The distances measured with the help of Zipoid software.

(2) To measure distance between two localities based on actual (on ground route) ArcGIS software's network analyst application was used; in which actual road, rail and sea distances are used for distance calculation.
(3) To calculate lead time for land route option; by road time is calculated between two localities with the help of distance and average speed of the 40 feet container. Whereas majority of distances between two locations were based on sea route; to calculate lead time for sea routes containerized ships, port transit time data were obtained from APL cargo and shipping, a subsidiary of Singapore-based Neptune Orient Lines which is a global transportation and logistics company engaged in shipping and related businesses as was these lead times were confirmed from the commercial feasibility study conducted by the chamber of commerce of the United States[48].

Transportation distances for each segment are calculated by applying above explained method and tabulated in Table 2. In Table 2, if the distances measured by both techniques (i.e. by aerial method and by on ground method) were the same, then only one type of ground distance is mentioned. However, if the distances measured for any particular segment was not same; (due to two types of calculations by aerial method and by on ground method) then both aerial distance as well as actual distance on ground are tabulated.This on ground distances are tabulated in bold letters with * mark over letter, moreover in subsequent calculations these ground distances (by sea, rail orroad) areapplied instead of distance covered in air. This actual road rail, or sea, transition time and port rotational time data was used in further scenarios, which helped in calculatinglead times. The final results demonstrates that stock manufactured at central Chinese location has to cover long distances before it could reach to anymarket situated in any country of Arabian peninsula, or any country of Africa, or any country of Europe or even any country of North America. 


\section{APPLICATION OF SCENARIO PALANNING IN CASE STUDY}

The LARG paradigm framework is tested by comparing and analysis of different scenarios for containerized merchandises case study from Central China to the Middle East, Europe and North American continent countries. Endeavor is made to reduce transportation distance and lead times which are common factor in existing four SCM paradigms. Several scenarios were created in which various route opportunities are assessed to find out best optimally possible Economic Corridor. This optimally identified Economic Corridor will offer premeditated benefit to the Eastern-Asian region, Southern-Asian region, Pakistan, China, Middle Eastern region in Asian continent generally and North African, European and Northern American continents countries specifically. This case study will also contribute to UN-Global initiative to obtain the advantages from the decrease in global warming and GHG (Greenhouse

TABLE 2. MINI SCENARIOS

\begin{tabular}{|c|c|}
\hline First Station to Second Station Distance & Distance (nm) \\
\hline From Central China to Port of Shanghai & 1192/1350* \\
\hline From Port of San Francisco to Port of Shanghai & 5346 \\
\hline From Port of San Diageo to Port of Shanghai & 5741 \\
\hline From Port of Gwadarto Port of Shanghai (Land Route) & 2886/3950* \\
\hline From Port of Gwadar to Port of Shanghai (Sea Route) & 4820 \\
\hline From China Central to Port of Gwadar(Land Route) & $1932 / 2600 *$ \\
\hline From Port of Aden to Port of Gwadar & 1442 \\
\hline From Port of Cairo to Port of Aden & 1279 \\
\hline From Port of Casablanca to Port of Cairo & 1989 \\
\hline From Port of Casablanca to Port of New York & 3133 \\
\hline From Port of San Francisco to Port of New York & $2240 / 2527^{*}$ \\
\hline From Port of Gwadarto Port of New York & 6319/7843^ (^by Sea) \\
\hline From Panama-Canal to Port of New York & 1924 \\
\hline From Port of San Francisco to Panama-Canal & 2698 \\
\hline From Port of New York to Port of Shanghai (Directly by Air) & 6415 \\
\hline $\begin{array}{l}\text { From Port of New York and then by passing through Port of San Francisco (by Land option } \\
\text { )and then passing through the Pacific Ocean then Port of Shanghai and finally toCentral China }\end{array}$ & 9223 \\
\hline $\begin{array}{l}\text { From Port of New York then passing through the Atlantic Oceanthen Panama canal then Port of Shangh } \\
\text { ai (by Pacific Ocean) and finallytoCentral China }\end{array}$ & 11048 \\
\hline $\begin{array}{l}\text { From Port of New York through Atlantic Ocean then through Suiz canal then through Gwadarthe } \\
\text { n land route and finally toCentral China }\end{array}$ & 10442 \\
\hline From Port of Singapore to Port of Shanghai & 2049 \\
\hline From Port of Colombo to Port of Singapore & 1469 \\
\hline From Port of Gwadarto Port of Colombo & 1301 \\
\hline From Port of Aden to Port of Colombo & 2093 \\
\hline From Port of London to Port of Casablanca & 1609 \\
\hline From London via Sea route to Port of Shanghai & 7220 \\
\hline $\begin{array}{l}\text { From Gwadar via Sea route passing nearby Colombo, Singapore then Port of Shanghai and } \\
\text { finally toCentral China }\end{array}$ & 6170 \\
\hline From London then Hamburg via land route toCentral China & $4157 / 6050^{*}$ \\
\hline $\begin{array}{l}\text { From London via (Sea route) through Atlantic Ocean then through Suiz canal then through Port o } \\
\text { f Shanghai and finally to Central China }\end{array}$ & 11838 \\
\hline $\begin{array}{l}\text { From London through Atlantic Ocean then through Suiz canal then through Gwadar then land route an } \\
\qquad \text { d finally to Central China }\end{array}$ & 8918 \\
\hline
\end{tabular}

Mehran University Research Journal of Engineering \& Technology, Volume 36, No. 3, July, 2017 [p-ISSN: 0254-7821, e-ISSN: 2413-7219] 
Gases). As result of this study a new Economic Corridor/ route is proposed, which will also reduce transportation distance and lead time.

After critical analysis of distances tabulated in Table 2, total four logistics route scenarios were created, out of which first two scenarios are shown in Fig. 2, and last two scenarios are shown in Fig. 3. Majority of the Chinese ships end point are Arabian Peninsula, European or Northern American countries. Historically from Asian to Northern American countries majority of trade occurred through straight pathway, i.e. ships passes from the
Pacific Ocean, ships mainly de-load goods to the ports situated on the western coastal harbors of the Canada, Mexico and United States of America, due to which westernharbors are sufferingovercrowding, as these have attained their throughput [49]. Alternatively there are two route options, but these two route options are comparatively longer and follow the longer path (Fig. 2 Route-1). Alternativelyfirst route also passfrom the Pacific Ocean (but bit southwardly), then this route passes through the Canal of Panama and ultimately this route ends up at one of Northern America's country seaport. (Fig. 2 Route-2).

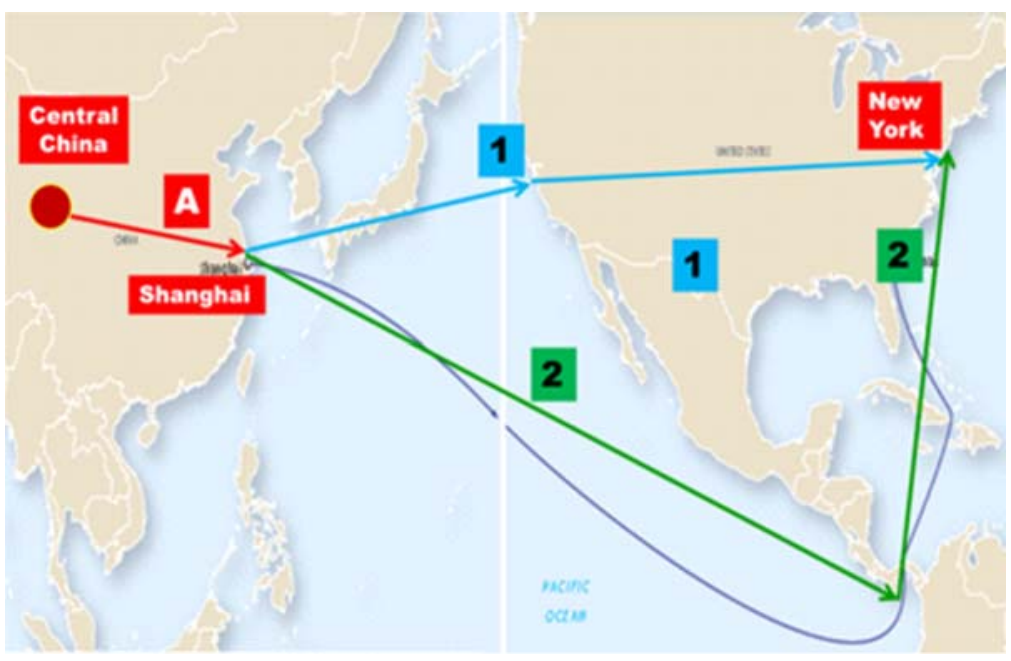

FIG. 2. ROUTE -1 AND 2 FROM CHINA CENTRAL TO THE PORT OF NEW YORK

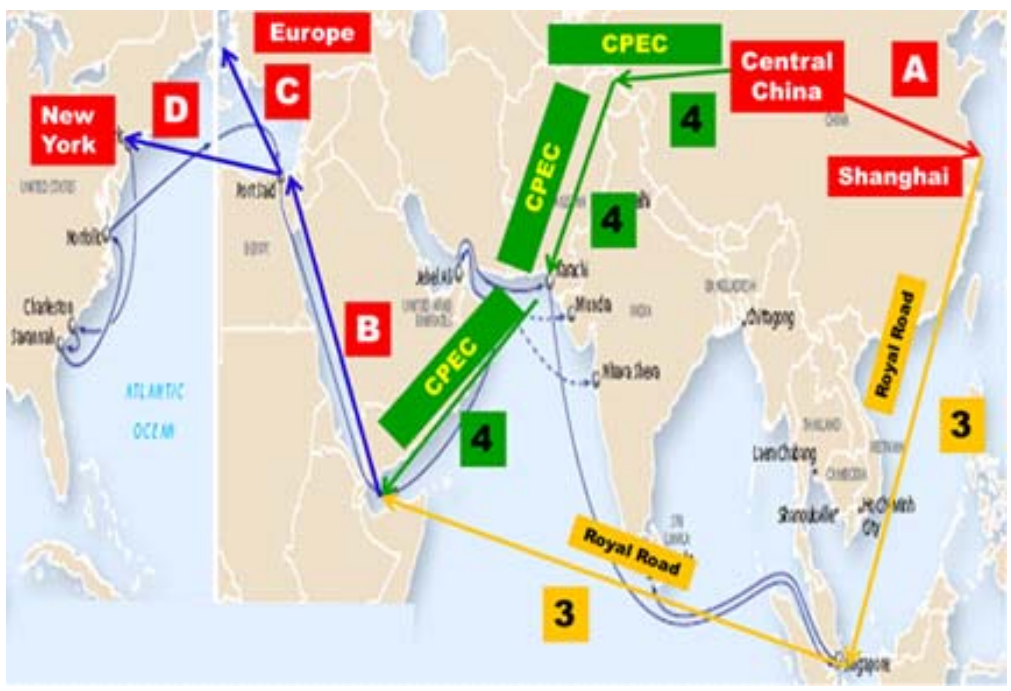

FIG. 3. ROUTE-3 AND 4 (SCENARIO C AND D) 
Second alternative available for North American route initially originates from central China and then from one of eastern harbor city of China then it passes nearby straits of Malacca. After passing through Arabian Sea, then Gulf of Aden, then it passes through Suez Canal and after that once it reaches Atlantic Ocean this route splits into two different spikes one prong moves strait to North American countries and the other prong changes its direction towards right side i.e., towards European countries. For European and Middle Eastern and North African Countries this Suez Canal route is the only route in operation and in literaturethis route is known as Royal Road [36,39] (Fig. 3, Route-3). Around 35\% of overall total trade of the world usually uses this existing route. This Royal Road is the most common route used by the shipping vessels to transport merchandises from Asian to the European countries. Persistently following this Royal Road route (which is being a lounger route) results into extra distances and extended lead time. Resultantly it leads to extra total logistics cost and additional production of greenhouse gas emissions, which eventually results into additional globalwarming. All above mentioned complications encourage greatercontests, which force us to re-explore the prevailing transportation and shipping routes of the world's supply chain.Moreover it should also be investigated how world oldest trade route Silk Route (Fig. 3 Route Option-4) could be revived by augmenting this route into $\mathrm{CPEC}$. The capacity building and improvements in the CPEC route's infrastructure would offer numerous opportunities to improve and revitalize transportation and SC. Moreover it will promote green, long lasting and sustainable prosperity for the East-Asian, Middle Eastern, European or even for the Northern American region $[19,50,51]$.

In Fig. 2 two scenarios are marked as Route Options 1-2. In first two scenarios both route originates from China Central, then this route passes from the Shanghai port after that this route passes from the Pacific Ocean and ultimately this route terminate at one of the port of Northern American continent. Route Option-1, in Fig.2, this route once passesfrom the Pacific Ocean, then this route passes from one of the western coast port of the
Northern American continent (in this research, port finalized as port of San Francisco) after this portthis route uses thechoiceof land route to finally terminate at one of the eastern side coast port of Northern American continent (in this research, port finalized as port of New York). However in Fig. 2 Route Option-2 till port of Shanghai the route is same but when it enters into the Pacific Ocean, it tilts southwards and passes through Panama Canal, afterwards this route passes nearbyWest Indies island then it enters into Atlantic Ocean and finally this route ends up at port of New York along with the Route Option-1.

In Fig. 3 two more scenarios are generated, as Options-3 and 4. The scenario depicted as Option-3 up to the Shanghai's port this route trails similar route as used in route Options-1 and 2, however, subsequentlyonce the port of Shanghai is left, Route Option-3 uses alternate pathway by moving in most southward direction passing nearby the straits of Malacca and Singapore, then it enters into Indian Ocean, passing through the Canal of Suez, once this route enters into Atlantic Ocean there it bifurcates into two parts and marked as Option C-D, Option-C moves straight towards west and ultimately terminate at port of the New York City. While Option-D of Route-3 after bifurcation at Atlantic Ocean moves upwards on toward north to terminate at Europe. Whereas Route Option-3 is the only existing trade route from China to the region of Middle East African and European continent; which is known in literature as Royal Road[36]. Whereas, route Option-4 is modified new route; this route is introduced as CPEC. Although this is not altogether a new route, because basically it is the revitalization ofold cargo route option which is known as Silk Road. This route also starts from Central China, but moves in opposite direction towards west on land route enters into Pakistan through Kara-Kuram Highway, after that this route uses Pakistanihighways and then passing through port of Gwadar and Arabian Sea; finally it joins, with Route Option-3 near Gulf of Aden, there after Route Options-3 and 4 are same. These scenarios were created and four 
route options were generated to measure and classify shortest possible route option from China Central to Middle Eastern, African, European and North American countries. Results of all these scenarios are compared with regards to advantages as well as disadvantages and presented in the form of Table 3.

After analysis of mini scenarios presented in table 1 and comparing four full scenarios presented in Figs. 2-3 following could easily be established from results:

The comparative analysis of different scenarios shows that, the modified Silk Road (Route Option-4C) CPEC reduces distance by almost $2767 \mathrm{~nm}$, which is the much shorter route as compared with the Route Option-3C (traditional Royal Road) for middle eastern and European countries. Moreover, this Economic Corridor route option will also reduce lead time by almost 7-8 days as compared to traditional Royal Road route option. Direct beneficiaries of this reduced transportation distance and lead time would be Middle Eastern, North African, Central and Western European countries.
(2) This modified Silk Road (Route Option-4D) CPEC is shorter route for even eastern region of North American continent as compared to Route Option-2 (using Panama Canal). This new Route$4 \mathrm{D}$ reduces distance fromCentralChina to port of New York, by $722 \mathrm{~nm}$ and reduction in lead time is around 4 days as compared to traditional Route Option-2 (using Panama Canal).

\section{VALIDATION OF FRAMEWORK WITH THE HELP OF CPEC CASE STUDY}

Thequantitative resultshave been summarized in section 6(1) and (2) as well as presented in Table 3 by comparing advantages and disadvantages of all four route options.However these quantitative results could further be utilized with the help of application of scenario planning as qualitative technique for the validation of LARG paradigm framework by using CPEC as a case study. The analysis of quantitative results indicate that CPEC scenario Route Option-4C reduces transportation distances and lead times significantly, which were

TABLE 3. ADVANTAGES AND DISADVANTAGES OF ALL 4 TRADE ROUTES

\begin{tabular}{|c|c|c|}
\hline Route Option & Advantages & Disadvantages \\
\hline Route-1(PacificOcean) & $\begin{array}{ll}\text { - } & \text { Shortest distance and lead time (for North } \\
\text { American continent only) } \\
\text { - } \quad \text { No bottle neck involved } \\
\text { No navigational locks involved }\end{array}$ & $\begin{array}{l}\text { Limited capacity as west ports of North } \\
\text { America have reached throughput } \\
\text { Not suitable for Middle eastern and } \\
\text { European countries }\end{array}$ \\
\hline Route-2 (Panama Canal) & - $\quad$ Could handle limited surplus cargo & $\begin{array}{l}\text { - } \quad \text { Panama canal locks involved } \\
\text { - Longer than route } 1 \text { and } 4 \mathrm{C}\end{array}$ \\
\hline Route-3C, 3D (Royal Road) & $\begin{array}{l}\text { - } \quad \text { 3C was only route pre CPEC } \\
\text { - } \quad \text { No bottle neck involved 3C, 3D } \\
\text { 3C\&D has less overland distance }\end{array}$ & $\begin{array}{l}\text { - } \quad \text { Suez canal involved 3C, 3D } \\
\text { - } \quad \text { Extended distances and lead times 3C, 3D }\end{array}$ \\
\hline Route-4C, 4D (CPEC) & $\begin{array}{l}\text { - } 4 C \text { has almost } 1 / 3 \text {, lesser distance as } \\
\text { compared to } 3 C^{-1} \\
\text { 4C has almost } 1 / 4 \text { lesser lead times as } \\
\text { compared to } 3 C \\
\text { - } 4 D \text { has lesser distance and lead times as } \\
\text { compared to 3D } \\
\text { 4C is more Lean, Agile and Green route } \\
\text { option as 3C }\end{array}$ & $\begin{array}{l}\text { - } \quad \text { Suez canal involved 4C, 4D } \\
\text { 4C\&D has greater overland distance } \\
\text { \&chances of accidents } \\
\text { - } \quad \text { Bottle neck (Himalaya range) } \\
\text { - } \quad \text { Non all weather to calamities } \\
\text { - } 4 \text { C is Less resilient route option as } \\
\text { compared to 3C }\end{array}$ \\
\hline
\end{tabular}

Mehran University Research Journal of Engineering \& Technology, Volume 36, No. 3, July, 2017 [p-ISSN: 0254-7821, e-ISSN: 2413-7219] 
assumed to be critical success factors. The qualitative results based upon these success factorsare described in following paragraphs: CPEC as Lean Option: Analysis of CPEC scenario (4C) reveals that SC is Lean owing to huge reduction in transportation distances and lead times.Itwould reduce the need of extra safety stock of inventories tremendously due to quick replenishment of inventories as compared to Route Option-3C.

CPEC as Agile Option: Deliveries of goods commonly termed as outbound logistics in SC would bemuch faster as compared to previous practices once $3 \mathrm{C}$ route option was being followed. This argument helps us to concur, thatCPEC route is anagile option.

CPEC as Green Option: Reduction in travel distance and time would lead to lesser fuel consumption and costs, resulting into reduced GHG emissions and carbon footprints. This makes this option comparatively more environment friendly as for $3 \mathrm{C}$ route.So it can be safely claimed that CPEC route option is the Green option. Reduction in GHG and carbon foot prints will impart sustainability in the SCs as well as in social life.

(4) CPEC as ResilientOption: The comparative advantages of this route are slightly hampered because of vulnerabilities to landslides at Himalayan Ranges ( $400 \mathrm{~nm}$ ), despite the fact that lesser distances and lead times in turn adds to the resilience of SC. However, this impediment could effectively be addressed by constructing ware houses in the mid-way of the 4C Route;Karachi and Gwadar port cities are ideal locations where warehouses can be built, for keeping safety stock of inventories for any uncertain contingencies. Further these port cities could ideally be improved into logistics and transit hubs. This will underpin the resilience aspect of this route making it a resilient option.

(5)

CPEC as LARG Paradigm FrameworkOption: Usage of CPEC route option will reduce transportation distance and lead time for SCs, which will result in a quick, agile and lean response; as well as will help in greening global logistics and imparting resilience in SC. Resultantly it will integrate sustainability in global logistics and SCM. Moreover these reductions in transportation distance and lead time are common factors among existing four SCM paradigms. This can facilitate to achieve common ground for their integration forming the basis of LARG paradigm; by using strategy of tradeoffs and decoupling points. Lean manufacturing practicesat Chinese plants, after decoupling, Agile response in logistics till Arabian Sea portsand then using the location of Arabian Sea ports as another decoupling point.Resilience in our supply chains can be enhanced, by building warehouses for strategic safety stock reserves at these sea ports. Lastly we can achieve Green practices through reduction of transportation distances and lead time by reducing GHG. Above arguments help us to conclude that application of CPECroute option provides us an opportunity to integrate LARG paradigm in our existing SCM practices as well as validation of LARG paradigm framework.

\section{CONCLUSION}

One difficulty allied with following this modified CPEC route is that although it shrinks the total distance; but the transportation distance covered by road portion is slightly increased. This way the probabilities of road blockage and traffic mishaps could be increased compare to previous practice. Nevertheless this problem can be managed proficiently through capacity enrichment of the 
current infrastructure and also by enhanced road management. The cost incurred on capacity enrichment will be very less as compared to the economic profits gained. Reduction in transportation distance and lead time provide a common ground, where we can integrate and align LARG paradigm; so as optimum and synergetic results can be achieved. Not with standing with any one SCM paradigm permanently and placing the SC strategy at central location amongst the existing four SCM Paradigms. Provides opportunity to move towards any one particular SCM Paradigm according to the situation and when situation normalizes falling back to its original central location. This central common ground LARG paradigm framework is based on a strategy which demands insurance of reduction in transportation distances and lead time; which will ultimately promote, reduction of greenhouses gases, reduction in consumption of energy, reduction of inventories as well as warehouse handling cost, reduction of total logistics cost and most importantly enhances sustainability in the system.

\section{ACKNOWLEDGEMENTS}

The authors are thankful to Prof. Dr. Muhammad Abbas Chaudhary, Ex-Vice Chancellor, University of Engineering \& Technology, Taxila, Pakistan, and Prof. Dr. Nawar Khan, for his cooperation in the completion of this study.

\section{REFERENCES}

Lee, S.W., Song, D.W., and Ducruet, C., "A Tale of Asia's World Ports: The Spatial Evolution in Global Hub Port Cities”, Geoforum, Volume 39, No. 1, pp. 372-385, 2008.

Pedersen, P.O., "Freight Transport under Globalisation and Its Impact on Africa”, Journal of Transport Geography, Volume 9, No. 2, pp. 85-99, 2001.

Sohail, M.S., Sayeed, M.A., Al-Fadhil, A., and Sahin, O.G., "Strategic Supply Chain Integration and Its Impact on Organisation Performance: Perspectives from an Emerging Nation”, International Journal of Integrated Supply Management, Volume 5, No. 1, pp. 62-80, 2009.
Stevens, G.C., "Integrating the Supply Chain”, International Journal of Physical Distribution \& Materials Management, Volume 19, No. 8, pp. 3-8, 1989.

[5] Christopher, M., and Towill, D.R., "Supply Chain Migration from Lean and Functional to Agile and Customised", Supply Chain Management: An International Journal, Volume 5, No. 4, pp. 206-213, 2000.

[6] Gunasekaran, A., Patel, C., and Tirtiroglu, E., "Performance Measures and Metrics in a Supply Chain Environment”, International Journal of Operations \& Production Management, Volume 21, No. 1/2, pp. 71-87, 2001.

[7] Reichhart, A., and Holweg, M., "Lean Distribution: Concepts, Contributions, Conflicts”, International Journal of Production Research, Volume 45, No. 16, pp. 3699-3722, 2007.

[8] Croom, S., Baramichai, M., Zimmers Jr, E.W., and Marangos, C.A., "Agile Supply Chain Transformation Matrix: An Integrated Tool for Creating an Agile Enterprise”, Supply Chain Management: An International Journal, Volume 12, No. 5, pp. 334-348, 2007.

[9] Tang, C.S., "Robust Strategies for Mitigating Supply Chain Disruptions”, International Journal of Logistics: Research and Applications, Volume 9, No. 1, pp. 33-45, 2006.

[10] Srivastava, S.K.,"Green Supply Chain Management:A State-of-the-Art Literature Review”, International Journal of Management Reviews, Volume 9, No. 1, pp. 53-80, 2007.

[11] Azevedo, S.G., Carvalho, H., and Cruz-Machado, V., “A Proposal of Larg Supply Chain Management Practices and a Performance Measurement System”, International Journal ofe-Education, e-Business, e-Management and e-Learning, Volume 1, No. 1, 2011.

[12] Azfar, K.R.W., "Finding Common Ground for Alignment of Supply Chain Paradigms”, 6th International Days of Statistics and Economics, pp. 586-593, Prague, 2012.

[13] Azfar, K.R.W., Khan, N., and Gabriel, H.F., "Performance Measurement: A Conceptual Framework for Supply Chain Practices”, Procedia-Social and Behavioral Sciences, Volume 150, pp. 803-812, 2014.

[14] Cabral, I., Espadinha-Cruz, P., Grilo, A., Puga-Leal, R., and Cruz-Machado, V., "Decision-Making Models for Interoperable Lean, Agile, Resilient and Green Supply Chains”, Supply Chain Management An International Journal, Volume 2, No.1, pp.12-17. 2011. 
[15] Carvalho, H., and Cruz-Machado, V., "Integrating Lean, Agile, Resilience and Green Paradigms in Supply Chain Management (Larg_Scm)”, Proceedings of 31st International Conference, pp. 3-14, 2009.

[16] Espadinha-Cruz, P., Grilo, A., Puga-Leal, R., and CruzMachado, V., “A Model for Evaluating Lean, Agile, Resilient and Green Practices Interoperability in Supply Chains”, IEEE International Conference on Industrial Engineering \& Engineering Management, pp. 1209-1213, 2011.

[17] Figueira, S., Machado, V.C., and Nunes, I.L., "Integration of Human Factors Principles in Larg Organizations- A Conceptual Model”, Work: A Journal of Prevention, Assessment and Rehabilitation, Volume 41, No. 1, pp. 1712-1719, 2012.

[18] Arawati, A., and Mohd, S.H., "Lean Production Supply Chain Management as Driver Towards Enhancing Product Quality and Business Performance: Case Study of Manufacturing Companies in Malaysia”, International Journal of Quality \& Reliability Management, Volume 29, No. 1, pp. 92-121, 2012.

[19] Agarwal, A., Shankar, R., and Tiwari, M.K., "Modeling the Metrics of Lean, Agile and Leagile Supply Chain: An Anp-Based Approach”, European Journal of Operational Research,Volume 173, No. 1, pp. 211-225, 2006.

[20] Cabral, I., Grilo, A., Leal, R.P., and Machado, V.C., "Modelling Lean, Agile, Resilient, and Green Supply Chain Management”, Proceedings of 33rd International Conference on Information Technology Interfaces, pp. 365-370, 2011.

[21] Cox, A., and Chicksand, D., "The Limits of Lean Management Thinking:Multiple Retailers and Food and Farming Supply Chains”, European Management Journal,Volume 23, No. 6, pp. 648-662, 2005.

[22] Dao, V., Langella, I., and Carbo, J., "From Green to Sustainability: Information Technology and an Integrated Sustainability Framework", The Journal of Strategic Information Systems, Volume 20, No. 1, pp. 63-79, 2011.

[23] Dias, J.C.Q., Calado, J.M.F., Osório, A.L., and Morgado, L.F., "Rfid Together with Multi-Agent Systems to Control Global Value Chains”, Annual Reviews in Control,Volume 33, No. 2, pp. 185-195, 2009.
Helena, C., Susana, D., and Machado, V.C., "Lean, Agile, Resilient and Green: Divergencies and Synergies”, International Journal of Lean Six Sigma,Volume 2, No. 2, pp. 151-179, 2011.

[25] Carvalho, H., Azevedo, S.G., and Cruz-Machado, V., "Supply Chain Performance Management: Lean and Green Paradigms”, International Journal of Business Performance and Supply Chain Modelling, Volume 2, No. 3, pp. 304-333, 2010.

[26] Carvalho, H., and Cruz-Machado, V., "Integration of Lean, Agile, Resilience and Green Paradigms in Supply

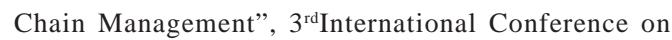
Management Science \& Engineering Management, pp, 4-13, 2009.

[27] Olhager, J., and Östlund, B., “An Integrated Push-Pull Manufacturing Strategy”, European Journal of Operational Research,Volume 45,No. 2, pp. 135-142, 1990.

[28] Mitra, K., Gudi, R.D., Patwardhan, S.C., and Sardar, G., "Towards Resilient Supply Chains: Uncertainty Analysis Using Fuzzy Mathematical Programming”, Chemical Engineering Research and Design,Volume 87, No. 7, pp. 967-981, 2009.

[29] Stock, J.R., "A Research View of Supply Chain Management: Developments and Topics for Exploration", ORiON: The Journal of ORSSA, Volume 25, No. 2, pp. 13-18, 2009.

[30] Panitch, L., and Gindin, S., "The Integration of China into Global Capitalism”, International Critical Thought,Volume 3, No. 2, pp. 146-158, 2013.

[31] Roelfsema, H., and Zhang, Y., "Globalization and Regional Innovation in China”, Discussion Paper Series, Volume 1, No. 1, pp. 12-15, 2012.

[32] Wei, Y., and Liefner, I., "Globalization, Industrial Restructuring, and Regional Development in China”, Applied Geography,Volume 32, No. 1, pp. 102-105, 2012.

[33] Bai, X., and Hu, J., "Study on Modern Service Industry Based on the Industrial Cluster”, Proceedings of 2nd International Conference on Green Communications and Networks, Volume 3, pp. 189-194, 2013. 
[34] Deng, X., Zhong, H., Bai, X., Zhao, T., and Wang, M., "Opportunities and Challenges for Development of Urbanization in Western China”, Chinese Journal of Population Resources \& Environment,Volume 3, No. 1, pp. 1-8, 2013.

[35] Somanathan, S., Flynn, P.C., and Szymanski, J.K., "Feasibility of a Sea Route through the Canadian Arctic", Maritime Economics \& Logistics, Volume 9, No. 4, pp. 324-334, 2007.

[36] Verny, J., and Grigentin, C., "Container Shipping on the Northern Sea Route”, International Journal of Production Economics, Volume 122, No. 1, pp. 107-117, 2009.

[37] O'connor, K., "Global City Regions and the Location of Logistics Activity”, Journal of Transport Geography, Volume 18, No. 3, pp. 354-362, 2010.

[38] Lau, K.H., and Wang, Y., "Reverse Logistics in the Electronic Industry of China: A Case Study”, Supply Chain Management: An International Journal, Volume 14, No. 6, pp. 447-465, 2009.

[39] Khan, R.W.A., Khan, N., and Chaudhary, M.A., “Green Supply Chain Management-Global Opportunities and Challenges: A Case Study”, IEEE International Summer Conference of Asia Pacific, Business Innovation and Technology Management, pp. 5-9, 2011.

[40] Holmqvist, M., and Pessi, K., “Agility through Scenario Development and Continuous Implementation: A Global Aftermarket Logistics Case”, European Journal of Information Systems, Volume 15, No. 2, pp. 146-158, 2006 .

[41] Lorenzoni, I., Jordan, A., Hulme, M., Kerry Turner, R., and O'riordan, T., “A Co-Evolutionary Approach to Climate Change Impact Assessment: Part-I. Integrating Socio-Economic and Climate Change Scenarios”, Global Environmental Change,Volume 10, No. 1, pp. 57-68, 2000 .

[42] Ringland, G., and Schwartz, P.P., "Scenario Planning: Managing for the Future”, Sloan Management Review, Volume 36, No. 2, pp. 25, 1995.

[43] Shackley, S., and Deanwood, R., "Constructing Social Futures for Climate-Change Impacts and Response Studies: Building Qualitative and Quantitative Scenarios with the Participation of Stakeholders", Climate Research,Volume 24, No. 1, pp. 71-90, 2003.
[44] Büyüközkan, G., Arsenyan, J., and Ruan, D., "Logistics Tool Selection with Two-Phase Fuzzy Multi Criteria Decision Making: A Case Study for Personal Digital Assistant Selection”, Expert Systems with Applications, Volume 39, No. 1, pp. 142-153, 2012.

[45] Lun, Y.V., Hilmola, O.-P., Goulielmos, A.M., Lai, K.-H., and Cheng, T.E., "Transportation Logistics: A Case Study of Bio-Diesel Factory Location Plans”, Oil Transport Management,pp. 91-103, Springer, 2013.

[46] Seuring, S., and Gold, S., "Sustainability Management Beyond Corporate Boundaries: From Stakeholders to Performance”, Journal of Cleaner Production, Volume 16, No. 15, pp. 1699-1710, 2013.

[47] Winter, M., and Knemeyer, A.M., "Exploring the Integration of Sustainability and Supply Chain Management: Current State and Opportunities for Future Inquiry”, International Journal of Physical Distribution \& Logistics Management,Volume 43, No. 1, pp. 18-38, 2013.

[48] Waasshhiinnggttoonn, W., "Land Transport Options between Europe and Asia: Commercial Feasibility Study”, Chamber of Commerce, United States of America, 2006, 8th OSCE Economic and Environmental Forum Part-1, Vienna, 1-2 February, 2010.

[49] Bomba, M., "Shifting Us-China Maritime Logistical Patterns: The Potential Impacts on Us Gulf Coast Ports”, Center for Transportation Research, University of Texas, Austin, 2004http://onlinepubs. trb. org/onlinepubs/ archive/Conferences/MTS/4C\% 20 Bomba Paper. pdf (Accessed June 2016).

[50] Khan, R.W.A., Khan, N., and Chaudhary, M.A., “Green Supply Chain Management-Global Opportunities and Challenges: A Case Study”, IEEE International Summer Conference of Asia Pacific,Business Innovation and Technology Management, pp. 5-9, 2011.

[51] Wick, C., Koppers, L., and Klumpp, M., “Total $\mathrm{CO}_{2}$ Calculation in Scm", Proceedings of $16^{\text {th }}$ International Working Seminar on Production Economics, 6th International Working Seminar on Production Economics, Volume 2, pp. 587-598, Innsbruck, 2010. 